\title{
ANALISIS NILAI MOTIVASI DALAM LIRIK LAGU "MERAIH BINTANG" KARYA PARLIN BURMAN SIBURIAN (ANALISIS SEMIOTIKA DE SAUSURE)
}

\author{
Muhdie Amir Karim \\ Fakultas Adab dan Ilmu Budaya, Universitas Islam Negeri Sunan Kalijaga, Yogyakarta \\ Email:muhdieamirk@gmail.com
}

Masuk : 05-08-2020, revisi: 25-10-2020, diterima untuk diterbitkan : 31-10-2020

\begin{abstract}
Song is a work of art created from the creation of events that the author has seen, felt, heard, and experienced. Likewise, the parlinary song "Meraih Bintang" by Burman Siburian has a meaning that contains a million messages and messages for listeners. This study aims to determine the values of the meaning of motivation contained in the lyrics of the song "Meraih Bintang". This research is a qualitative descriptive with a semiotic approach according to Ferdinand de Saussure. Sources of data in this study are the lyrics of the song "Meraih Bitang. Researchers applied reading and note-taking techniques to collect data. The data analysis technique used is based on the Miles and Huberman model. The results showed that the lyrics of the song "Meraih Bintang" have a motivational value as shown in the first verse, namely the songwriter specifically dedicates this song to athletes to compete with enthusiasm and never give up. In the second verse, the meaning is found in order to achieve a dream, we must have strong faith and pray to the Creator. The third verse by the songwriters says that in order to reach our dreams, we must focus on one goal. The fourth stanza is that the songwriter tries not to give up easily in achieving dreams. The fifth stanza is conveyed that we must cooperate with determination, sportsmanship and solidarity in a competition.
\end{abstract}

Keywords: Ferdinand de Saussure, song, lyric, motivation, semiotics.

\begin{abstract}
ABSTRAK
Lagu merupakan karya seni yang tercipta dari hasil kreasi terhadap peristiwa yang dilihat, dirasa, didengar, dan juga pernah dialami langsung oleh penulis. Sama halnya dengan lagu "Meraih Bintang" karya Parlin Burman Siburian memiliki makna yang mengandung sejuta pesan dan amanat untuk para pendengar. Penelitian ini bertujuan untuk mengetahui nilai-nilai makna motivasi yang terdapat pada lirik lagu "Meraih Bintang". Penelitian ini merupakan kualitatif deskriptif dengan pendekatan semiotika menurut Ferdinand de Saussure. Sumber data dalam penelitian ini adalah lirik lagu "Meraih Bitang". Peneliti menerapkan teknik baca dan catat untuk mengumpulkan data. Teknik analisis data yang digunakan berdasarkan model Miles dan Huberman. Hasil penelitian menunjukkan bahwa lirik lagu "Meraih Bintang" memiliki nilai motivasi yang ditunjukan pada bait pertama yaitu pencipta lagu secara khusus mempersembahkan lagu ini untuk para atlet agar berkompetisi dengan semangat dan pantang menyerah. Pada bait kedua ditemukan makna demi meraih suatu mimpi, kita harus mempunyai keyakinan yang kuat serta berdoa kepada sang Khalik. Bait ketiga pencipta lagu menyampaikan untuk menggapai mimpi, kita harus fokus pada satu tujuan. Bait keempat disini pencipta lagu mencoba mengajak untuk tidak mudah berputus asa dalam meraih mimpi. Bait kelima disampaikan bahwa tekad, sportifitas dan solidaritas harus kita gandeng dalam suatu kompetisi.
\end{abstract}

Kata Kunci: Ferdinand de Saussure, lagu, lirik, motivasi, semiotika.

\section{PENDAHULUAN}

Hampir di seluruh penjuru dunia manusia pernah mendengarkan musik, karena musik merupakan salah satu media hiburan. Selain berfungsi sebagai media hiburan, musik juga dapat menjadi perantara untuk mengkomunikasikan pemahaman penciptanya. Hal ini karena pada hakikatnya musik adalah produk pikiran yang dapat membangkitkan suasana hati dan mempengaruhi pikiran atau tindakan seorang manusia. Musik juga bagian dari sebuah karya seni. Seni adalah bagian penting dalam sistem peradaban manusia yang terus bergerak sesuai dengan perkembangan budaya, teknologi dan ilmu pengetahuan (Soeharto, 1992). 
Musik adalah cara yang dilakukan pencipta lagu dalam mengungkapkan perasaan dan pikiran yang dituangkannya lewat unsur-unsur musik yang meliputi struktur lagu, melodi, bentuk, irama dan ekspresi sebagai kesatuan yang tidak terlepaskan didalamnya demi menghasilkan sesuatu bentuk karya bunyi dalam bentuk lagu (Muttaqim, 2008). Pada dasarnya, lagu merupakan karya sastra yang bentuknya mirip dengan puisi, dan letak perbedaanya adalah lagu itu dinyanyikan. Sama halnya dengan karya sastra lainnya, pengarang ingin menyampaikan pesan kepada pendengarnya. Selain itu, lagu dianggap sebagai media yang universal dan evektif untuk menyalurkan gagasan, dan ekpresi pengarang melalui lirik, nada, serta pembawaan lagu oleh musisi (Saraswati, 2018). Disisi lain, lirik juga mempunyai makna tersirat pada tiap struktur kalimatnya. Makna tersebut dapat membangun kognisi serta menciptakan sebuah wacana baik berkaitan dengan seseorang, sesuatu maupun peristiwa di sekitarnya (Fadillah, 2019).

Dalam menciptakan sebuah lagu, penulis lagu menyusun dan memilih kata-kata dalam lirik lagu menggunakan gaya bahasa untuk memperindah sebuah lagu yang dibuat dan tentunya lirik lagu tersebut, memiliki makna yang mengandung sejuta pesan dan amanat untuk para pendengar. Salah satu lagu yang menggambarkan pesan nilai motivasi adalah lagu "Meraih Bintang" karya Parlin Burman Siburian. Lagu ini menceritakan tentang semangat juang para atlet demi meraih kemenangan dan menjunjung tinggi sportivitas melalui lagu tersebut dalam pegelaran acara Asian Games 2018 di Jakarta. Via Vallen adalah seorang penyanyi ternama di Indonesia yang terpilih untuk menyanyikan lagu Official Theme Song tersebut.

Motivasi dapat diartikan sebagai segala bentuk yang bisa dijadikan pendorong perbuatan yang mendorong seorang individu dalam memenuhi kebutuhannya. Dalam ini, motivasi mejadi gaya untuk menggerakan prilaku (the energizer) juga sekaligus menjadi suatu penentu prilaku. Menurut M. Utsman Najati, motivasi merupakan kekuatan yang mampu menggerakan dan membangkitkan aktivitas pada manusia dan makhluk hidup dan menimbulkan tingkah laku sekaligus menggerakannya ke arah yang menuju suatu tujuan tertentu. Motivasi mempunyai tiga komponen utama, yaitu mengarahkan, menopang, dan menggerakkan (Daulay, 2014). Jadi dapat disimpulkan bahwa kontruksi nilai motivasi merupakan sebuah aktivitas yang tujuanya untuk membangun suatu dorongan terhadap orang lain yang mengandung pemikiran perubahan yang kuat untuk meraih suatu keinginan yang ingin digapai.

Maka dari itu, penulis tertarik meneliti lagu "Meraih Bintang" dibandingkan dengan lagu-lagu yang lainnya karena dalam lagu tersebut mengandung nilai motivasi. Di samping itu lirik yang indah dan mudah diingat yang terkandung didalam lagu "Meraih Bintang" bisa dengan mudah dimengerti, dipahami, bahkan dihafal oleh pendengar bahkan lagu ini sangat populer karena telah di cover dalam berbagai bahasa. Lirik lagu ini sangatlah erat kaitannya akan nilai motivasi yang syarat akan unsur penyemangat dalam hal apapun dan tetap menjunjung tinggi sportivitas. Sebagai sebuah pesan komunikasi, musik dan lagu mampu menyampaikan amanat motivasi dalam kehidupan seseorang untuk mendorong mereka dalam melakukan sesuatu yang menjadi cinta-citanya dan demi terwujudnya suatu hasil yang jauh lebih baik. Lirik lagu ini mampu menginspirasi para pendengar terutama kalangan remaja.

Berdasarkan penjelasan yang tertera pada latar belakang di atas, maka penulis merumuskan pemasalahan dalam penelitian ini dalam fokus: Bagaimana nilai-nilai motivasi yang terkandung di dalam lirik lagu "Meraih Bintang" karya Parlin Burman Siburian? 


\section{METODE PENELITIAN}

Penulis dalam penelitian ini menggunakan jenis penelitian Deskriptif-Kualitatif. Penelitian ini bertujuan untuk mendeskripsikan serta menggambarkan arti dan makna serta tanda-tanda nilai motivasi dalam lirik lagu "Meraih Bintang" karya Parlin Burman Siburian yang dinyanyikan Via Vallen menurut fakta-fakta yang nyata atau tanpa dibuat-buat. Sedangkan penelitian kualitatif merupakan suatu penelitian yang hasilnya berupa temuan-temuan yang tidak bisa didapatkan melalui statistik ataupun dengan cara kuantifikasi lainnya. Dengan menerapkan metode penelitian kualitatif peneliti berusaha mengetahui, memahami, menjelaskan, dan menganalisa dan menghasilkan data deskriptif berupa kata-kata tertulis. (Suharsaputra, 2012). Sumber data merupakan data yang dikumpulkan oleh peneliti baik primer maupun sekunder (Siswanto, 2012). Dalam hal ini data primer yang digunakan adalah video clip lagu yang dilihat dari youtube. Sedangkan sumber data sekunder dalam penelitian ini diperoleh dari referensi yang mendukung baik itu berupa buku, artikel, maupun jurnal yang bersumber dari internet. Peneliti menerapkan teknik baca dan catat dalam teknik pengumpulan data.

Adapun teknik baca dilakukan dalam upaya mencari keterangan dan informasi yang terkait dengan data penelitian. Serta, teknik baca juga sekaligus menghadirkan pemahaman yang lebih luas bagi peneliti dalam memahami objek. Adapun teknik catat dilakukan untuk menulis datadata nilai motivasi yang telah ditemukan sebagai objek analisis. Kemudian data-data tersebut dihimpun dengan cara ditulis lalu dikelompokkan (Kaelan, 2012). Setelah data valid terkumpul dalam penelitian ini akan dianalisis dengan menerapkan teknik analisis data model Miles dan Huberman. Menurutnya, ada empat kategori tahapan dalam menganalisis data kualitatif, yaitu: pengumpulan data, reduksi data, pemaparan data, dan verifikasi kesimpulan (Sugiyono, 2008).

Pendekatan semiotika menurut Ferdinand de Saussure mengembangkan dasar-dasar teori linguistik umum. Kekhasan teorinya terletak pada kenyataan. Dia menganggap bahasa sebagai sistem tanda. Menurut Saussure tanda-tanda, khususnya tanda-tanda kebahasaan, setidaktidaknya memiliki dua buah karakteristik primordial, yaitu bersifat linier dan arbitrer (Budiman, 1999). Yang terpenting dalam pembahasan pokok pada teori Saussure adalah prinsip yang mengatakan bahwa bahasa adalah suatu sistem tanda, dan setiap tanda itu tersusun dari dua bagian, yaitu signifier (penanda) dan signified (petanda).

Menurut Saussure bahasa merupakan suatu sistem tanda (sign). Tanda dalam pendekatan Saussure merupakan manifestasi konkret dari citra bunyi dan sering diidentifikasi dengan citra bunyi sebagai penanda. Jadi penanda (signifier) dan petanda (signified) merupakan unsur mentalistik yang mana di dalam tanda terungkap citra bunyi ataupun konsep sebagai dua komponen yang tak terpisahkan. Dengan kata lain, kehadiran yang satu sangat berarti pula kehadiran yang lain seperti dua sisi kertas. Hubungan antara penanda dan petanda bersifat bebas (arbiter), baik secara kebetulan maupun ditetapkan. Arbiter dalam pengertian penanda tidak memiliki hubungan alamiah dengan petanda (Masinambow, dalam Sobur 2003).

Dari gagasan batasan pengertian tersebut itu dapat diketahui adanya tiga unsur produk yang tercangkup didalamnya yakni, makna adalah hubungan antara bahasa dengan dunia luar, penentuan hubungan terjadi karena kesepakatan para pemakai, perwujudan makna itu dapat digunakan untuk menyampaikan informasi sehingga dapat saling dimengerti. Semua model makna memiliki bentuk yang secara luas serupa atau mirip. Masing-masing memperhatikan tiga unsur yang mesti ada dalam setiap studi tentang makna. Ketiga unsur tersebut adalah: a) tanda, b) acuan tanda, c) pengguna tanda. Tanda merupakan sesuatu yang bersifat fisik, bisa dipersepsi 
oleh indera kita. Saussure berpendapat "Tanda terdiri atas bentuk fisik plus konsep mental yang terkait, dan konsep ini merupakan pemahaman atas realitas eksternal” (Suprapto, 2006).

Motivasi merupakan nama lain dari membangkitkan motif. Motif dalam bahasa Inggris Motive yang berarti suatu gerakan. Gerakan itu merupakan bagian dari tingkah laku manusia. Pada bidang psikologi motivasi adalah suatu rangsangan yang menjadi dasar seseorang bertingkah laku untuk mencapai tujuan tertentu. Nilai motivasi dalam sebuah lagu dapat mempengaruhi seorang pendengar ikut larut terhadap pemikiran sang pecipta lagu. Motivasi yang didapatkan dari menikmati sebuah lagu merupakan jenis motivasi internal dan motivasi eksternal bergantung rangsangan yang ditimbulkan (Anggraeni, Yarno, Hermoyo, 2019). Ada beberapa penyebab yang bisa mempengaruhi terjadinya motivasi yakni faktor Internal dan faktor eksternal. Faktor internal Merupakan faktor motivasi yang muncul dalam diri seseorang. Motivasi ini muncul akibat adanya keinginan seorang individu untuk menggapai suatu prestasi serta rasa tanggungjawab dalam hidupnya. Sedangkan faktor eksternal merupakan faktor yang berasal dari luar diri seorang individu. Motivasi terbentuk akibat adanya pengaruh dari luar, misalnya organisasi yang ikut serta membentuk dan menentukan perilaku individu dalam hidupnya (Kadarisman, 2012). Menurut Mclelland (dalam Beck, 1990), ada tiga hal yang melatar belakangi motivasi seseorang:

a. The Need for Achievement (n-ach) - Kebutuhan akan Prestasi. Pencapaian Kebutuhan akan prestasi adalah kebutuhan seseorang untuk memiliki pencapaian signifikan, menguasai berbagai keahlian, atau memiliki standar yang tinggi.

b. The Need for Authority and Power (n-pow) - Kebutuhan akan Kekuasaan. Kebutuhan ini didasari oleh keinginan seseorang untuk mengatur atau memimpin orang lain.

c. The Need for Affiliation ( $n$-affil) - Kebutuhan akan Afiliasi Keanggotaan. Kebutuhan ini adalah kebutuhan yang didasari oleh keinginan untuk mendapatkan atau menjalankan hubungan yang baik dengan orang lain.

Lirik lagu merupakan simbol verbal yang diciptakan oleh manusia. Manusia adalah makhluk yang tahu bagaimana harus bereaksi, tidak hanya terhadap lingkungan fisiknya, namun juga pada simbol-simbol yang dibuatnya sendiri (Rivers, Jesen, \& Peterson, 2003). Sementara menurut pendapat Awe (2003), lirik Lagu merupakan ekspresi seseorang tentang suatu hal yang sudah dilihat, didengar maupun dialaminya. Dalam mengekspresikan pengalamannya, penyair atau pencipta Lagu melakukan permainan kata-kata dan bahasa untuk menciptakan daya tarik dan kekhasan terhadap lirik atau syairnya. Permainan bahasa ini dapat berupa permainan vokal, gaya bahasa maupun penyimpangan makna kata dan diperkuat dengan penggunaan melodi dan notasi musik yang disesuaikan dengan lirik lagunya sehingga pendengar semakin terbawa dengan apa yang dipikirkan pengarangnya (Awe, 2003). Dari pengertian di atas dapat disimpulkan lirik lagu merupakan karya seni yang tercipta dari hasil kreasi terhadap peristiwa yang dilihat, dirasa, didengar, dan juga dialami langsung oleh penulis lagu.

Lirik lagu "Meraih Bintang"

Setiap saat, setiap waktu

Keringat basahi tubuh

Ini saat yang kutunggu

Hari ini ku buktikan

$\mathrm{Ku}$ yakin aku kan menang

Hari ini kan dikenang

Semua doa kupanjatkan

Sejarah kupersembahkan 
Terus fokus satu titik, hanya itu titik itu

Tetap fokus kita kejar lampaui batas

Terus fokus satu titik hanya itu titik itu

Tetap fokus kita kejar dan raih bintang

Yo yo ayo... yo ayo yo yo ayo... yo ayo

Yo ayo yo... yo ayo Yo yo...00o...ooo

Yo yo ayo... yo ayo yo yo ayo... yo ayo

Yo yo ayo...kita datang, kita lihat, kita menang

Kalau menang berprestasi

Kalau kalah jangan frustrasi

Kalah menang solidaritas

Kita galang sportifitas

Terus fokus satu titik, hanya itu titik itu

Tetap fokus kita kejar dan raih bintang

(18 ${ }^{\text {th }}$ Asian Games 2018, 2018).

\section{HASIL DAN PEMBAHASAN}

Pesta Olahraga Asia 2018 (bahasa Inggris: 2018 Asian Games, XVIII Asiad), secara resmi dikenal sebagai Pesta Olahraga Asia ke-18 dan Jakarta-Palembang 2018, adalah ajang olahraga wilayah Asia yang diselenggarakan dari 18 Agustus sampai 2 September 2018 di Indonesia, tepatnya di kota Jakarta dan Palembang. Tahun 2018, Indonesia kali kedua menjadi tempat pagelaran Asean Games. Indonesia menjadi tuan rumah pertama kali tahun 1962. Asian Games pertama kali disiarkan di seluruh televisi dunia pada tahun 1970 (Tangkudung \& Fikri, 2019). Sebagai tuan rumah dalam ajang pesta olahraga tersebut masyarakat Indonesia pun antusias dan ikut berpartisipasi dalam menyukseskan ajang ini, salah satu bentuk semangat serta kesungguhan negara ini dalam menyambut dan mensukseskan pesta pegelaran olahraga yang bergengsi tersebut adalah dengan terciptanya lagu "Meraih Bintang" oleh Parlin Burman Siburian yang dulu sempat bergabung dengan grup band Slank dan lagu tersebut beraransemen music perpaduan dangdut dan pop modern (Rofiq, 2018). Lagu ini bercerita mengenai semangat para atlet demi meraih kemenangan dengan tetap menjunjung tinggi sportifivitas dan dalam lagu ini juga menampilkan nilai motivasi yang sangat kuat.

Dengan mempertimbangkan berbagai aspek untuk memperkenalkan dangdut sebagai musik khas Indonesia kepada masyarakat Internasional, akhirnya panita Asean Games menjatuhkan pilihan kepada Via Vallen untuk menyanyikan lagu "Meraih Bintang" dalam Asean Games 2018 ini. Pemilihan Via Vallen juga didasarkan atas talentanya yang luar biasa dan juga besarnya pengaruh musikalitasnya di Indonesia saat ini. Lagu tersebut diharapkan mampu membuat masyarakat Indonesia berpesta, bergoyang, membakar serta menambah semangat, juga sekaligus merangkul dan mengajak rakyat Indonesia untuk bersama-sama mendukung dan berpartisipasi menyukseskan ajang pesta olahraga Asean Games 2018 (Rofiq, 2018). Maka dari itu, pada kesempatan ini penulis berupaya untuk menganalisis lirik lagu "Meraih Bintang" dengan menerapkan teori semiotika Ferdinand de Saussure, yang mempunyai lirik sebagai berikut: 
Tabel 1. Bait 1

\begin{tabular}{ll}
\hline Aspek Penanda & Aspek Petanda \\
\hline Setiap saat setiap waktu & Lirik ini menjadikan petanda adalah saat seorang \\
Keringat basahi tubuh & pencipta lagu menceritakan perjuangan atlet yang \\
Ini saat yang kutunggu & terus berlatih tanpa lelah sampai keringat bercucuran \\
Hari ini ku buktikan & membasahi tubuhnya demi memberikan hasil yang \\
& optimal dalam ajang perlombaan Asian Games 2018 \\
& yang sudah di depan mata. Ajang ini merupakan \\
& perlombaan yang sangat dinanti-natikan oleh para atlet \\
untuk membuktikan eksistensi menjadi atlet terbaik & yang membanggakan negaranya. \\
\hline
\end{tabular}

Dalam pemaparan bait pertama terlihat bahwa pencipta lagu secara khusus mempersembahkan lagu ini untuk para atlet supaya berkompetisi dengan semangat pantang menyerah, fokus, dan sportif pada satu tujuan yakni kemenangan. Karena pada pegelaran Asean Games ini para atlet dituntut untuk membuktikan usaha dan jerih payahnya selama ini dalam berlatih agar bisa mempersembahkan sebuah kemenangan bagi negara yang tentunya akan dikenang oleh seluruh masyarakat. Setiap waktu merupakan rangkaian suatu proses, perbuatan atau keadaan yang kita kerjakan dengan penuh semangat dan berjuang sekuat tenaga agar kita dapat memberikan hasil yang terbaik dan membuktikan bahwa kita dapat menyelesaikan tugas kita. Sebagai manusia kita selayaknya terus berusaha dan berjuang demi menggapai suatu impian dan cita-cita selagi kita masih diberikan waktu, kesehatan, dan kesempatan.

Tabel 2. Bait 2

\begin{tabular}{ll}
\hline Aspek Penanda & Aspek Petanda \\
\hline Ku yakin aku kan menang & Lirik di bait ke dua merupakan lanjutan dari bait yang \\
Hari ini kan dikenang & pertama yaitu untuk bisa mewujudkan keinginan \\
Semua doa kupanjatkan & seorang atlet menjadi atlet terbaik yang \\
Sejarah kupersembahkan & membanggakan negaranya harus ditempuh dengan \\
& bertanding. Di dalam pertandingan seorang atlet \\
& dituntut harus mempunyai sikap totalitas dan optimis \\
& untuk bisa meraih sebuah kemenangan. Sebab hanya \\
& kemenanganlah yang bisa membuat mereka dikenang. \\
& Tapi, tidak hanya perjuangan dan semangat saja yang \\
& dibutuhkan oleh para atlet. Namun, doa juga harus \\
tetap dipanjatkan untuk menggapai berkah dan & ridhoNya. Sehingga sebuah sejarah bisa \\
dipersembahkan untuk negeri tercinta.
\end{tabular}

Keyakinan seharusnya di tanamkan pada diri kita masing-masing supaya kita tetap optimis dalam menjalankan tugas kita secara maksimal. Dan dengan keyakinan tersebut akan membantu kita dalam mengerjakan tugas sehingga dapat membuahkan hasil dan mengukir kenangan terbaik dalam hidup kita, serta menjadi motivasi bagi diri sendiri dan orang lain yang berada dilingkungan sekitar kita. Selain keyakinan yang harus kita tanamkan, ada juga doa yang harus kita panjatkan untuk mencari ridho yang Maha Agung sehingga kita berhasil dalam hal tersebut dan dapat menorehkan sejarah untuk kehidupan kita kedepannya. Kita juga harus pandai bersyukur dengan apa yang telah diraih. Karena, hal tersebut tidaklah serta merta hasil dari usaha kita sendiri. Akan tetapi, Tuhan yang Maha Esa yang memberikan jalan serta meridhoi apa yang telah kita upayakan dan menjawab doa yang telah kita panjatkan. Manusia berhak berencana tetapi Tuhanlah yang menentukan. Percayalah bahwa ada energi lain yang mengatur segala kejadian di alam semesta ini, termasuk keberhasilan dalam meraih sesuatu yang kita impikan. Sebagai manusia kita selayaknya terus selalu optimis dan berpikir positif terhadap apa yang sudah kita usahakan dan perjuangkan. Karena, dengan sikap positif maka hal yang akan terjadi 
juga akan bernilai positif begitu pula sebaliknya. Jika kita berpikiran negatif dan pesimis, maka hasil yang nantinya kita peroleh juga tidak akan maksimal. Karena, sikap pesimis yang ditanamkan akan melemahkan semangat manusia dalam berusaha dan berjuang.

Tabel 3. Bait 3

\begin{tabular}{ll}
\hline \multicolumn{1}{c}{ Aspek Penanda } & \multicolumn{1}{c}{ Aspek Petanda } \\
\hline Terus fokus satu titik, hanya itu titik itu & Pada bait ini pencipta lagu menyampaikan bahwa \\
Tetap fokus kita kejar lampaui batas & setiap orang dapat menggapai mimpinya, apabila ia \\
Terus fokus satu titik, Hanya itu titik itu & tetap konsisten dan fokus pada satu tujuan. Fokus \\
Tetap fokus kita kejar dan raih bintang & merupakan kata kunci dalam mewujudkan semua \\
& harapan dan cita-cita yang ingin kita raih. Bintang di \\
& langit dijadikan sebagai simbol penghargaan untuk \\
& para juara. Untuk mendapatkannya, para atlet harus \\
& membayarnya dengan jerih payah dan doa. \\
\hline
\end{tabular}

Keberhasilan adalah suatu yang kita tunggu setelah berupaya semaksimal mungkin. Dalam mencapai keberhasilan kita harus tetap fokus dalam satu tujuan agar sampai pada titik yang kita tuju. Untuk itu, bila kita ingin meraih impian buatlah skala prioritas. Fokus bukan hanya tentang melihat pada satu titik, tetapi bagaimana juga untuk tidak menghiraukan hal-hal yang tidak sejalan dengan tujuan yang ingin kita capai, menghargai proses, sabar karena usaha tidak akan pernah menghianati hasil. Dalam berusaha kita sebaiknya terfokus pada satu tujuan yang kita impikan. Karena jika kita fokus terhadap segala hal yang kita impikan maka hasil didapatkan akan lebih maksimal dibandingkan jika kita melakukan banyak hal dan tidak fokus, sebab di dalam fokus terdapat sebuah konsistensi. Dengan fokus kita akan memusatkan segala perhatian, tenaga serta usaha hanya dalam satu hal tersebut. Dan kita harus selalu menanamkan api semangat yang kuat, tekad yang bulad demi meraih mimpi yang telah kita gantung setinggitingginya dan tidak akan menyerah sebelum impian tersebut digapai.

Tabel 4. Bait 4

\begin{tabular}{ll}
\hline Aspek Penanda & Aspek Petanda \\
\hline Yo yo ayo... yo ayo Yo yo ayo... yo ayo & Pada bait ini pencipta lagu memberikan makna akan \\
Yo yo ayo... yo ayo Yo yo.. ooo... ooo & sebuah perjuangan yang merupakan hal nyata dalam \\
Yo yo ayo... yo ayo Yo yo ayo... yo ayo & $\begin{array}{l}\text { sebuah kehidupan. Sehingga kita dituntut untuk gigih } \\
\text { dalam berjuang dan tidak boleh pesimis dalam meraih } \\
\text { Yo yo ayo.. Kita datang, kita lihat, kita menang }\end{array}$ \\
\hline
\end{tabular}

Setiap orang punya mimpi dan cita-cita. Dalam menggapai cita-cita dan mimpi tersebut seseorang harus berusaha dan semangat untuk meraihnya dan harus dibarengi tekad dan kemauan yang kuat untuk meraih cita-cita dan impiannya. Terlebih jika kita adalah orang yang dipilih untuk mewakili nama bangsa maka kita akan lebih bersungguh-sungguh dalam upaya mengharumkan nama bangsa dan negara. Karena, secara tidak langsung kita adalah orang yang dipilih dari sekian juta rakyat Indonesia untuk mengikuti ajang perlombaan Asean Games. Maka dari itu, kita harus benar-benar bertekad menjadi yang terbaik dan menjadi pemenang dalam kompetisi Asean Games ini dengan demikian kita dapat membuat bangsa Indonesia bangga. Kita harus benar-benar mengupayakan semua harapan dan impian yang telah bangsa ini mandatkan kepada kita sebagai orang yang terpilih.

Tabel 5. Bait 5

\begin{tabular}{ll}
\hline \multicolumn{1}{c}{ Aspek Penanda } & \multicolumn{1}{c}{ Aspek Petanda } \\
\hline Kalau menang berprestasi & Pada bait ini pencipta lagu mencoba menyampaikan \\
Kalau kalah jangan frustasi & bahwa kemenangan dan kekalahan adalah hal yang \\
Kalah menang solidaritas & wajar. Tetap semangat dan berusaha untuk menjadi \\
\hline
\end{tabular}



kalah adalah hal yang biasa. Asian Games merupakan salah satu bentuk ajang mempererat silaturahim di antara sesama atlet dan rasa persaudaraan hendaknya tetap terjaga. Selain adanya semangat tinggi untuk memenangkan pertandingan, sikap sportifitas harus tetap dijunjung agar sebuah kompetisi dapat mencapai hasil yang maksimal dan tidak hanya mementingkan kemenangan semata.

Kompetisi diperlukan sebagai tolak ukur kemampuan diri. Dari situlah, kita bisa mengintropeksi dan menganalisa seberapa jauh dan mampu kita bersaing dengan lawan-lawan tangguh. Ketika kita berkompetisi akan menjadikan diri lebih baik dari sebelumnya. Kompetisi adalah suatu ajang yang mana beberapa orang saling berlomba untuk mengetahui kemampuan yang dimilikinya. Dalam kompetisi tentu saja ada pihak yang menang dan begitu pula sebaliknya. Siapapun yang menang patut dihargai karena prestasinya. Begitupun yang kalah patut dihargai karena dianggap telah berupaya seoptimal mungkin demi memberikan yang terbaik. Ketika kita berhasil mendapatkan kemenangan tersebut kita harus tetap bersikap rendah hati dan tidak sombong. Namun jika sebaliknya, maka janganlah frustasi dan tetap menjaga solidaritas dan sportifitas antara peserta.

Dalam suatu pertandingan meskipun kita gagal dan belum meraih target yang diimpikan tetaplah berjiwa besar dan tidak menyerah pada titik itu saja. Akan tetapi, kita ditutut untuk tetap semangat, lebih giat lagi dalam berusaha untuk mengapai impian yang belum sempat terwujud pada kesempatan yang akan datang. Dalam berkompetesi kita harus tetap menjunjung tinggi rasa persahabatan dan solidaritas demi terwujudnya ikatan persahabat serta perdamaian yang erat diantara sesama manusia khususnya negara-negara ASEAN yang tergabung dalam event kejuaraan Asean Games. Masing-masing dari kita boleh saja bersaing dan berkompetisi untuk meraih kemenangan. Akan tetapi setiap pesaing haruslah bersaing dan berlomba dengan cara yang baik dan sehat. Meskipun kita bersaing bukan berarti pesaing kita adalah musuh ataupun lawan. Diluar dari event Asean Games kita tetaplah sahabat dan saudara sesama negara Asia. Maka dari itu, kita harus tetap menjaga dan menjunjung erat nilai solidaritas dan sportifitas.

Lagu "Meraih Bintang" menjadi bukti nyata dapat menjadi pelecut motivasi para atlet yang berkompetisi dalam ajang Pegelaran Asian Games 2018 yang mana Indonesia selaku tuan rumah pada ajang kali berhasil mendulang total 98 mendali dengan rincian 31 mendali emas, 24 mendali perak, dan 43 mendali perunggu. Jumlah mendali emas yang didapatkan pada Asian Games itu sudah melampaui target awal. Dengan raihan mendali ini, Indonesia mengakhiri Asean Games 2018 di posisi keempat kelasemen peraih mendali. Selain untuk para atlet lagu ini pun dapat pula untuk dijadikan motivasi secara pribadi. Misalkan saja, ketika sedang merasa drop, lelah, putus asa, dan lain sebagainya, maka dengan mendengarkan lagu ini bisa mengalirkan energi positif di pikiran dan semangat kita. Karena sejatinya, hidup itu adalah sebuah perjuangan. Semua orang mengalami hal-hal seperti apa yang ada dalam lirik lagu ini, entah itu jatuh bangun, tertawa, menangis, menyerah. Namun, dibalik itu semua, ada titik dan waktu tersendiri dimana kita bisa bangkit dari semua hal itu. Sebab waktu terus berjalan seperti derasnya air yang mengalir. Jadi, mari kobarkan semangat, terus tersenyum, fokus pada satu tujuan, dan bangkit dari keterpurukan. 


\section{KESIMPULAN DAN SARAN}

Adapun hasil dari penelitian yang telah dilakukan penulis dalam penelitian ini, adalah sebagai berikut:

1. Dalam pemaparan bait pertama terlihat bahwa pencipta lagu secara khusus mempersembahkan lagu ini untuk para atlet agar berkompetisi dengan semangat pantang menyerah, fokus, dan sportif pada satu tujuan yakni kemenangan. Dari sini kita dapat mengambil hikmah bahwa janganlah menyia-nyiakan kesempatan yang diberikan, karena setiap kesempatan adalah bentuk perjuangan dalam menggapai impian. Sebagai manusia kita selayaknya terus berusaha dan berjuang demi menggapai suatu impian selagi kita masih diberikan waktu, kesehatan, dan kesempatan.

2. Dalam bait kedua makna yang terkandung setelah melalui proses analisa semiotik De Saussure adalah demi meraih suatu mimpi dan cita-cita, kita harus mempunyai keyakinan dan juga tetap beribadah dan berdoa kepada yang Maha Kuasa. Kita juga harus pandai bersyukur dengan apa yang telah diraih. Manusia berhak berencana tetapi Tuhanlah yang menentukan.

3. Bait ketiga pencipta lagu menyampaikan untuk menggapai mimpi dan cita-cita kita tetap harus fokus pada satu tujuan. Fokus merupakan kata kunci dalam mewujudkan semua harapan dan cita-cita yang ingin kita raih. Bintang di langit dijadikan sebagai symbol penghargaan untuk para juara. Untuk mendapatkannya, para atlet harus membayarnya dengan jerih payah dan doa. Hal ini ditunjukan dengan kalimat "Terus fokus satu titik, hanya itu titik itu. Tetap fokus kita kejar dan raih bintang". Melalui lagu "Meraih Bintang" menjadi bukti nyata dalam memotivasi para atlet Indonesia yang sedang berkompetisi yang dibuktikan dengan keberhasilan mendulang total 98 mendali dengan rincian 31 mendali emas, 24 mendali perak, dan 43 mendali perunggu. Jumlah mendali emas yang didapatkan pada Asean Games itu sudah melampaui target awal.

4. Bait keempat disini pencipta lagu mencoba mengajak untuk tetap semangat dalam melakukan pekerjaan sehingga mendapatkan hasil yang baik. Setiap orang punya mimpi dan cita-cita. Dalam menggapai cita-cita dan mimpi tersebut haruslah dibarengi dengan usaha dan semangat serta tekad dan kemauan yang kuat. Itulah yang harus ditanamkan di benak para atlet demi mempersembahkan kemenangan dan mengharumkan nama negara tercinta.

5. Bait kelima disampaikan bahwa tekad, sportifitas dan solidaritas harus kita gandeng dalam suatu kompetisi. Dalam berkompetesi kita harus tetap menjunjung tinggi rasa persahabatan dan solidaritas demi terwujudnya ikatan persahabat serta perdamaian yang erat diantara sesama manusia khususnya negara-negara ASEAN yang tergabung dalam event kejuaraan Asean Games. Masing-masing dari kita boleh saja bersaing dan berkompetisi untuk meraih kemenangan. Akan tetapi setiap pesaing haruslah bersaing dan berlomba dengan cara yang baik dan sehat. Meskipun kita bersaing bukan berarti pesaing kita adalah musuh ataupun lawan. Diluar dari event Asean Games kita tetaplah sahabat dan saudara sesama negara Asia.

Selain untuk para atlet lagu ini pun dapat pula untuk dijadikan motivasi secara pribadi. Misalkan saja, ketika sedang merasa drop, lelah, putus asa, dan lain sebagainya, maka dengan mendengarkan lagu ini bisa mengalirkan energi positif di pikiran dan semangat kita. Karena sejatinya, hidup itu adalah sebuah perjuangan. Semua orang mengalami hal-hal seperti apa yang ada dalam lirik lagu ini, entah itu jatuh bangun, tertawa, menangis, menyerah. Namun, dibalik itu semua, ada titik dan waktu tersendiri dimana kita bisa bangkit dari semua hal itu. Sebab waktu terus berjalan seperti derasnya air yang mengalir. Jadi, mari kobarkan semangat, terus tersenyum, fokus pada satu tujuan, dan jadilah seorang pemenang. 
Dari hasil penelitian yang telah dilakukan penulis sangat menyarankan diadaknnya penelitian lanjutan yang serupa terkait dalam kajian semiotika dalam lirik lagu. Hal ini dikarenakan lagu adalah suatu media pesan komunikasi yang digemari semua kalangan yang syarat akan pesan, simbol, dan makna yang terkandung didalam lirik lagunya.

\section{Ucapan Terima Kasih (Acknowledgement)}

Peneliti mengucapkan terima kasih kepada semua pihak yang telah mendukung dan terlibat selama pelaksanaan penelitian ini sehingga penelitian ini dapat berjalan dan diselesaikan dengan lancar.

\section{REFERENSI}

Anggraeni, W. M., Yarno., \& Hermoyo, R. P. (2019). Pesan nilai-nilai motivasi pada lirik lagu album monokrom (kajian Semiotka model Charles Sander Peirce). Jurnal Stilistika Pendidikan Bahasa dan Sastra, 12(1), 67-81. http://dx.doi.org/10.30651/st.v12i1.2443

Awe, M. 2003. Iwan Fals: Nyayian di tengah kegelapan. Ombak.

Beck, R.C. (1990). Motivation theories and principles: Third Edition. Upper Saddle River, NJ: Prentice-Hall.

Budiman, K. (1999). Kosa semiotika. Yogyakarta: LkiS.

Daulay, N. (2014). Pengantar psikologi dan pandangan Al-Qur'an tentang psikologi. Jakarta: Prenadamedia Group.

Fadillah, Y. (2019). Kritik dan realitas sosial dalam musik (Analisis wacana kritis pada lirik lagu karya Iksan Skuter "lagu petani”). Jurnal Commercium, 1(2), 113-118. https://jurnalmahasiswa.unesa.ac.id/index.php/Commercium/article/view/26971/24684

Kadarisman, M. (2012). Manajemen sumber daya manusia. Depok: Raja Grafindo Persada.

Kaelan. (2012). Metode penelitian kualitatif interdisipliner bidang sosiologi, budaya, filsafat, seni, agama, dan humaniora. Yogyakarta: Paradigma.

Muttaqin, M. (2008). Seni Musik Klasik untuk SMK. Jilid 2. Jakarta: Direktorat Pembinaan Sekolah Menengah Kejuruan, Direktorat Jenderal Manajemen Pendidikan Dasar dan Menengah, Departemen Pendidikan Nasional.

Rivers, L., W., Jensen, J. W., \& Peterson, T. (2003). Media massa masyarakat modern edisi kedua. Jakarta: Kencana Prenada Media.

$18^{\text {th }}$ Asian Games 2018. (2018, Juni 30). Reach for the stars - Via Valen - Official theme song asian games 2018 [Video]. Youtube. https://www.youtube.com/watch?v=1ak17RxcqBQ

Rofiq, A. (2018, September 4). Cerita dibalik lagu "meraih bintang" Asian Games, ada tangan dingin eks personal Slank. Jatim Times. https://jatimtimes.com/amp/baca/178563/20180906/185600/cerita-dibalik-lagu-meraihbintang-asian-Games-ada-tangan-dingin-eks-personel-slank

Saraswati, R. (2018). Analisis wacana kritis lirik lagu Mockingbird karya Eminem. Jurnal Pujangga, 4(1), 31-43. http://dx.doi.org/10.47313/pujangga.v4i1.498

Suharsaputra, U. (2012). Metode penelitian kuantitatif, kualitatis, dan tindakan. Refika Aditama. Siswanto. (2012). Metode penelitian kuantitatif, kualitatis, dan tindakan. Refika Aditama.

Sobur, A. (2003). Tesk media: Suatu analisis wacana, analisis semiotik, dan analisis farming. Jakarta: Remaja Rosda Karya.

Soeharto, M. (1992). Kamus musik. Jakarta: Gramedia Widia Sarana Indonesia.

Sugiyono. (2008). Metode penelitian kuantitatif kualitatif dan R\&D. Bandung: Alfabeta.

Suprapto, T. (2006). Pengantar teori komunikasi. Jakarta: Media Pressindo.

Tangkudung, J., \& Fikri, A. (2019). Asian games: Energi Indonesia baru. Samudra Biru Anggota IKAPI. 